\title{
Az interdiszciplináris kommunikáció jelentősége az állcsonti cysták megfelelő kórismézésében
}

\author{
Cserni Gábor dr. ${ }^{1,2}$ - Cserni Dorottya dr. ${ }^{3}$ \\ Zombori Tamás dr. ${ }^{2}$ - Baráth Zoltán dr. ${ }^{3}$ \\ ${ }^{1}$ Bács-Kiskun Megyei Oktatókórház, Patológiai Osztály, Kecskemét \\ ${ }^{2}$ Szegedi Tudományegyetem, Szent-Györgyi Albert Klinikai Központ, Patológiai Intézet, Szeged \\ ${ }^{3}$ Szegedi Tudományegyetem, Fogorvostudományi Kar, Fogpótlástani Tanszék, Szeged
}

Bevezetés: Az állcsonti cysták helytálló diagnosztikája a klinikai, radiológiai és patológiai leletek együttes értékelésével lehetséges. Korábbi munkánk során többször tapasztaltuk a klinikoradiopatológiai kommunikáció és korreláció hiányát, és ez olykor inadekvát diagnózisok felállításához vezetett.

Célkitüzés: Célunk ezen kommunikációs probléma mértékének becslése és annak bemutatása, hogy ez a hiányosság hogyan befolyásolhatja a diagnosztikát.

Módszer: Korábbi, más célú retrospektív elemzés újraértékelése történt a klinikai (radiológiai) adatközlés, a revízió kapcsán módosuló diagnózisok számszerúsítése céljából, valamint további 3 egyetemi patológiai intézet 10-10 anonimizált leletének vizsgálata az adatközlések vonatkozásában.

Eredmények: 2 intézményben 85 odontogen cysta diagnózisakor csupán a betegek életkora, neme volt 100\%-osan ismert. A lokalizációra vonatkozó adekvát információ 62\%-ban, a méretre vonatkozó csupán 29\%-ban fordult elő a szövettani kérőlapokon. Összességében a diagnózist segítő releváns információt csak 52\%-ban adtak meg. Az utólagos klinikoradiopatológiai korrelációra törekvő revízió során 38/85 esetben (45\%) módosult a végső diagnózis kisebb vagy nagyobb mértékben. A megküldött leletek alapján a klinikai/radiológiai adatok közlése $<50 \%$ és $100 \%$ közöttinek becsülhető más intézetekben is. Az 5 intézmény közül csak az egyikben utalt specializációra az, hogy minden leletet egy patológus véleményezett, általában sok patológus $(\mathrm{n}=25)$ valamelyike véleményezte a kevés tömlöt $(\mathrm{n}=105)$. A diagnózis kommunikáció hiányán alapuló kisiklásának lehetőségét 5 példával illusztráljuk: cysta radicularisként leletezett paradentalis, lobos follicularis és lateralis periodontalis cysta, ductus nasopalatinus cysta és radicularis cysta differenciáldiagnosztikáját példázó tömlő, valamint botryoid odontogen cysta kerül bemutatásra.

Következtetés : Az odontogen tömlők precíz diagnosztikája mind a klinikai, mind a patológiai oldalról javítást igényel, amelynek egyik része az ilyen irányú képzés lehet.

Orv Hetil. 2021; 162(12): 458-467.

Kulcsszavak: állcsonti cysta, odontogen cysta, keratocysta, differenciáldiagnózis

\section{The role of interdisciplinary communication in the proper diagnostics of jaw cysts}

Introduction: Proper diagnosis of jaw cysts requires the parallel evaluation of clinical, radiological and histopathological findings. Lack of clinico-radio-pathological correlation can lead to inconsistent diagnoses.

Objective: To evaluate the rate of lacking clinico-pathological communication and demonstrate how this may influence diagnostics.

Method: Data of a former retrospective analysis were re-evaluated to quantify the lack of clinical data communicated to pathologists and estimate the rate of final diagnoses requiring alteration after review of all available clinical data. 10 anonymized reports on odontogenic cysts from 3 university pathology departments each were analysed for the lack of relevant clinical information.

Results: Only the age and gender of patients were documented in 100\% for 85 jaw cysts diagnosed in 2 departments of pathology. Adequate information about cyst localization and size were communicated in $62 \%$ and $29 \%$, respectively. Overall, information relevant to the diagnosis was given in $52 \%$ of the cases. Revision based on clinico-radiopathological correlation led to alterations of the diagnosis in 38/85 cases (45\%). Based on reports from other institu- 
tions, the communication of clinical data is estimated to be between $<50 \%$ and $100 \% .25$ pathologists were involved in reporting 105 cysts. 5 cases illustrate how diagnosis may fail without good communication: a paradental, an inflamed dentigerous and a lateral periodontal cyst, each misdiagnosed as radicular cyst; a cyst raising the differential diagnosis of nasopalatine duct versus radicular cyst; a botryoid odontogenic cyst.

Conclusion: Proper diagnosis of jaw cysts requires improvements from both pathological and clinical sides, and could probably be improved through education.

Keywords: jaw cyst, odontogenic cyst, keratocyst, differential diagnosis

Cserni G, Cserni D, Zombori T, Baráth Z. [The role of interdisciplinary communication in the proper diagnostics of jaw cysts]. Orv Hetil. 2021; 162(12): 458-467.

(Beérkezett: 2020. augusztus 7.; elfogadva: 2020. augusztus 26.)

\section{Rövidítések}

bcl2 $=($ b-cell lymphoma- 2$)$ b-sejtes lymphoma- $2 ; \mathrm{CT}=(\mathrm{com}-$ puted tomography) számítógépes tomográfia; $\mathrm{OKC}=$ odontogen keratocysta; OPT $=$ ortopantomogram; SZTE $=$ Szegedi Tudományegyetem; $\mathrm{WHO}=$ (World Health Organization) Egészségügyi Világszervezet

Az odontogen cysták gyulladásos vagy fejlődési eredetûek lehetnek, és a WHO (Egészségügyi Világszervezet) jelenleg érvényes tumorosztályozási rendszere e szerint bontja két csoportra ôket (1. táblázat) [1]. Az egyes entitásokat klinikai, radiológiai és szövettani jellegzetességeik alapján lehet besorolni. Olykor nagyobb a hangsúly a szövettani képen, máskor azonban a szövettani megjelenés teljesen aspecifikus. Az odontogen keratocysták (OKC-k) hámbélése például jellegzetes, vékony parakeratosist mutató laphám az alsó sejtréteg paliszádállású magjaival és a felszín hullámos jellegével. Ugyanakkor a gyulladásos eredetư tömlők és a gyulladt fejlódési tömlók szöveti képe teljesen azonos lehet, lobsejtek mellett jellegtelen, többrétegú, el nem szarusodó laphám látható általában hámfosztott területekkel, és ilyenkor a szöveti kép a radicularis tömlőkre emlékeztet akkor is, ha más tömlőről van szó. Megjegyzendő még, hogy a gyulladásos eredetû radicularis cystákra és a felelős fog eltávolítása után megmaradó residualis cystákra egyaránt jellemző, hogy ha a gyulladást fenntartó ok megszúnik, a tömlők éretté válnak, és ilyenkor ellapult, fejlődési tömlőkéhez hasonló lesz a hámbélésük. Emiatt a klinikai és a fogászati radiológiai adatok egyaránt lényegesek a helyes kórismézéshez, és el kell fogadni azt is, hogy egyes esetekben nem adható pontos besorolás, legfeljebb csak valószínűsíthető az eredet.

Korábbi, 85 odontogen cysta klinikopatológiai revízióját alapul vevő és ez alapján a tömlők, különösen az OKC-k immunhisztokémiai festődésmintázatát elemző munkánk során szembesültünk azzal, hogy a klinikai/ radiológiai adatok gyakran hiányoznak a kórszövettani vizsgálatra küldött odontogen cysták vizsgálatkéró lapjairól. A szövettani vizsgálatok (olykor az ismert klinikai adatokat sem figyelembe véve vagy a nem közölt adatok miatt) a klinikummal, radiológiával összhangban nem álló kórszövettani diagnózisokhoz vezettek [2]. Ez különösen a ritkább entitások kapcsán mutatkozott meg.

A jelen közleménnyel az a célunk, hogy felhívjuk a figyelmet egyes ritkább entitásokra és arra, hogy a klinikai, a radiológiai és a szövettani kép együttesen hogyan vezethet helyes diagnózishoz, illetve a megfelelő adatközlés és/vagy kommunikáció hiánya milyen hibákat okozhat.

\section{Módszer}

2019 második és 2020 első felében a Szegedi Tudományegyetem Szent-Györgyi Albert Klinikai Központjának Patológiai Intézetében, valamint az egyetem BácsKiskun Megyei Oktatókórházának Patológiai Osztályán leletezett odontogen cysták retrospektív vizsgálatát végeztük. Ennek kapcsán a tömlők a lehető legalaposabb klinikoradiopatológiai revízió alá kerültek a klinikai adatok, az elérhető radiológiai képek és a szövettani metszetek ismételt vizsgálatával. Az anonimizált esetekről részletes szöveges és képi dokumentáció áll rendelkezésre korábbi közleményünknek a citokeratin-17 és a bcl2 (b-cell lymphoma-2) festődési mintázatait dokumentáló kiegészítő állományában [2]. Az esetek revíziója kapcsán néhány diagnosztikus tanulság levonására is sor került, és ennek megosztását, valamint néhány tanulságos eset részletesebb bemutatását tüztük ki a jelen közlemény céljaként.

Ezenfelül összegeztük az eredeti szövettani diagnózisok helytállóságát, a diagnózis felállításához szükséges klinikai/radiológiai adatok közlésének gyakoriságát. Tíz-tíz anonimizált lelet egyetemi patológiai intézetektől való bekérésével, szúrópróbaszerúen igyekeztünk felmérni azt, hogy máshol hogyan múködik a klinikopatológiai együttmúködés az odontogen cysták diagnosztikájában.

A közlemény tárgyát képező adatok retrospektív elemzése a Szegedi Tudományegyetem Szent-Györgyi Albert Klinikai Központja Humán Orvosbiológiai Intézményi és Regionális Kutatásetikai Bizottságának 26/2018SZTE hivatkozási számú engedélyével történt. 
1. táblázat | Állcsonti tömlők a WHO fej-nyak táji tumorokat osztályozó „kék könyve” alapján [1]

\begin{tabular}{|c|c|}
\hline Típus & Jellemzők \\
\hline \multicolumn{2}{|c|}{ 1. Inflammatoricus cysták } \\
\hline 1.1. Radicularis cysta & $\begin{array}{l}\text { Vitalitását elvesztett foghoz (kihúzott foghoz - residualis cysta) társul; maxilla>mandibula (kb. 50\% } \\
\text { anterior maxilla); a leggyakoribb; apicalis, jól körülírt, radiolucens laesio (ritkán lateralis gyökércsa- } \\
\text { torna: lateralis radicularis cysta) } \\
\text { Szövettan: lobos kötó- vagy sarjszövet, el nem szarusodó laphámbélés vegyes gyulladásos infiltrátum- } \\
\text { mal, árkádszerú hám-stroma határ (érett radicularis/residualis cysta: vékonyabb hám egyenletes(ebb) } \\
\text { hám-stroma határral), habos plazmájú macrophagok, koleszteringranuloma, Rushton-testek, muci- } \\
\text { nosus metaplasia, csillós sejtek, elszarusodó gócok előfordulhatnak }\end{array}$ \\
\hline
\end{tabular}

1.2. Inflammatoricus collateralis cysták

1.2.1. Paradentalis cysta

Vitális fogakhoz társul; pericoronitis, fájdalom, duzzanat, olykor trismus kíséri; nemritkán bilateralis; gyakorisági csúcs: $20-40$ év között, f/n arány $2 / 1$; részlegesen vagy a közelmúltban előtört fogak gyökerének buccalis oldalánál, a pericoronalis szövetek gyulladása következtében; alsó 3 . nagyőrlőknél, ritkán szemfognál/maxillában

Szövettan: a radicularis cystáétól megkülönböztethetetlen; a hámbélés összefügghet a cement-zománc átmenettel vagy a pericoronalis hámmal, a gyökér mellett letüremkedő tasak formájában

1.2. Inflammatoricus collateralis cysták

1.2.2. Mandibularis buccalis bifurcatiós cysta

Fájdalmatlan duzzanat, buccalis irányban ferde fog, mély tasak esetén (felülfertőződés mellett fájdalmas); jól körülírt, buccalisan élesen elhatárolt, radiolucens laesio, a mandibula alsó széléig terjedhet, periostealis reakció, laminált új csont képződése látható lehet; részlegesen vagy a közelmúltban előtört fogak gyökerének buccalis oldalánál, a pericoronalis szövetek gyulladása következtében; az alsó 1-2. nagyőrlóknél

Szövettan: a radicularis cystáétól megkülönböztethetetlen; a hámbélés összefügghet a cement-zománc átmenettel vagy a pericoronalis hámmal, a gyökér mellett letüremkedő tasak formájában

2. Fejlődési cysták

2.1. Fejlődési odontogen cysták

2.1.1. Follicularis („dentigerous”) cysta Elő nem tört fog nyakához kapcsolódó, a fog koronáját magába burkoló tömlő; gyakorisági csúcs: 10-40 év között, f/n arány $2 / 1 ; \mathrm{kb}$. 3/4-ük az alsó 3-as nagyőrlőknél, további gyakoribb előfordulás: felső 3-as, 8-as és alsó 5-ös fog; általában kicsi és tünetmentes (fertőzés esetén gyulladás, fájdalom lehet), de jelentôs méretet elérhet, fog elmozdulását okozhatja; éles határú radiolucens laesio, gyakran kortikált széllel; (ERUPTIÓS cysta: az előtörő fogak feletti lágyrészekben elhelyezkedő follicularis cysta)

Szövettan: lobmentes laza kötőszövetes tok, 2-4 sejtrétegú vékony hámbélés; a falban odontogen hámfészkek lehetnek; nyáktermelö, illetve csillós sejtek is lehetnek (metaplasia), Rushton-testek elöfordulhatnak; gyakran gyulladt, ilyenkor hámhyperplasia, koleszterinkristályok gyakran láthatók

2.1.2. Odontogen keratocysta

Jellegzetes hámja alapján definiált odontogen cysta; gyakorisági csúcs: 10-30 és 50-70 év között, f/n arány $2 / 1$ körüli, kb. 5\%-uk Gorlin-Goltz-szindróma részeként, fiatal korban jelentkezik; a PTCH1gén mutációja/inaktivációja szerepet játszik a kialakulásában; kb. 80\%-uk a mandibulában, felük a hátsó mandibulában, ramusban, de máshol is előfordulhat; általában tünetmentes, véletlenül felfedezett, jól elhatárolódó radiolucens elváltozások (nemritkán lobulált a szél, corticatio mutatkozik), melyek lehetnek uni- vagy multilocularisak, tipikusan anteroposterior irányú növekedés jellemzi ôket, ami miatt ritka a duzzanat, corticalis terjedés

Szövettan: jellegzetes; vékony, gyakran hullámos felszínú, parakeratoticus, basalis paliszádállású (focalisan megfordult magpolaritást mutató) sejteket tartalmazó hám szabályos hám-kötőszöveti határral; a hám bimbózást mutathat, satellitacysták, sejtfészkek lehetnek a falban

2.1.3. Lateralis periodontalis cysta Előtört fogak gyökerei között vagy gyökerétől lateralisan elhelyezkedő, el nem szarusodó hámmal (LPC)/Botryoid odontogen cysta bélelt tömlő (a BOC ennek multilocularis változata); gyakorisági csúcs: a 6. és 7. évtized között, f/n (BOC) arány $>1$; kb. 80\%-uk a mandibulában alakul ki (a nagyőrlő fogaktól elórefelé); általában tünetmentes; jól elhatárolódó, unilocularis (a BOC multilocularis) radiolucens elváltozás gyakran kortikált széllel; általában $<1 \mathrm{~cm}$ (a BOC nagy is lehet)

Szövettan: jellegzetes (a felnőtt gingivalis cystáéval analóg); 1-2 réteg vastagságú, el nem szarusodó hám gócos, plakkszerü (gyakran örvényes jellegú, olykor világos sejtes) megvastagodásokkal; a hám gyakran leválik a kötőszövetrôl, és olykor dens, hialinizált kötőszövetes sáv van közvetlenül a hám alatt

2.1.4. Gingivalis cysta

Alveolaris nyálkahártyán jelentkező cysták felnőttekben vagy csecsemőkben; felnőttekben a 40-60. év között szokott jelentkezni (csecsemókben gyakori; az újszülöttek kb. 90\%-ánál, 3 hónapon túl ritka), f/n arány $<1 ;$ kb. $3 / 4$ részük mandibularis, kisőrlő, szemfog tájékán (csecsemőknél a fogatlan alveolaris gerincen); apró, fájdalmatlan, hólyagcsára emlékeztető kékes kiboltosulás; röntgenfelvételen ritkán azonosítható (esetleg felszínesen erodálhatja a csontot)

Szövettan: lobmentes, LPC-re emlékeztet, a plakkok kifelé is nőhetnek; a falban a plakkokra emlékeztető hámszigetek előfordulhatnak; ritkán szélesebb többrétegú laphám a bélés (csecsemőkori változat ritkán kerül vizsgálatra, a vékony, elszarusodó hám tứnik jellemzőnek) 
1. táblázat folyt.

2.1.5. Glandularis odontogen cysta (GOC)

2.1.6. Kalcifikáló odontogen cysta
Mirigyhám- vagy nyálmirigy-differenciációt utánzó odontogen cysta; ritka, 40-70 év között a leggyakoribb, $\mathrm{f} / \mathrm{n}$ arány $\approx 1, \mathrm{~kb} .3 / 4$ részük mandibularis, a maxillaris laesiók az anterior területen fordulnak elö; uni- vagy multilocularis elváltozások, melyek lobuláltak lehetnek; általában több fog gyökerével függnek össze, a foggyökér felszívódása gyakori, akárcsak a fogelmozdulás (impaktált foghoz csak rendkívül kivételesen társul); nagy méretet érhet el

Szövettan: jellegzetes; a) a bélelő hám vastagsága változatos: $2-3$ rétegú ellapult hám és vastagabb, el nem szarusodó laphám; b) luminalisan legalább gócosan ún. bakancsszegsejtek (köbhám- vagy alacsony hengerhámsejtek); továbbá változatosan c) hámon belüli microcysták; d) luminalis sejtek apokrin metaplasiája; e) világos sejtek a basalis vagy parabasalis rétegekben; f) papillaris kiboltosulások; g) nyáktermelő sejtek; h) LPC-re emlékeztető hámgömbök, plakkok; i) csillós sejtek; j) olykor többrekeszes tömlők. Az első két jegy általános; mind jelen lehet, de leginkább csak legalább 7/10 jegy jelenléte esetén lehet a GOC megbízható szövettani diagnózisát felállítani

Ameloblastomaszerú hámbélés és gócos szellemsejtek jelenléte által definiált odontogen tömlő; ritka, széles életkorspektrum, az átlagéletkor 30 év körüli (odontomához társuló formája a 2. évtizedben a leggyakoribb), $\mathrm{f} / \mathrm{n}$ arány $\approx 1 ;$ mindkét állcsont elülső részén jellegzetes (az odontomához társuló forma az anterior maxillában szokott elhelyezkedni), csonton kívüli lokalizáció is előfordul $(10 \%$ körül); jól elhatárolódó, esetleg lobulált unilocularis laesio; a foggyökér felszívódása és a fogelmozdulás gyakori; kb. 50\%-ban meszesedés vagy odontoma társul hozzá; az extraossealis változat duzzanattal, fájdalommal, nyomásérzékenységgel járhat

Szövettan: jellegzetes; változó vastagságú hámbélés, basalis paliszádállású sejtréteggel, mely fölött a zománcszerv reticulum stellatum részének sejtjeire emlékeztető, ameloblastomára is jellemző sejtréteg van focalis szellemsejtekkel, melyek elmeszesedhetnek; a lumenbe ameloblastomaszerú vagy szellemsejtes proliferáció boltosulhat be; a kötőszövetes tokban szellemsejtek, hámszigetek vagy leánycysták előfordulhatnak; a hámbélés mellett dentinoid lerakódása is előfordul, odontogen tumorszerú részek is jelen lehetnek

2.1.7. Orthokeratoticus odotogen cysta Teljesen vagy döntően orthokeratosist mutató, többrétegú laphámmal bélelt odontogen tömlő; széles életkorspektumban, dominálóan a 3-4. évtizedben, f/n arány >1; 90\%-ban mandibularis, fóleg hátsó lokalizáció; gyakran tünetmentes vagy fájdalmatlan duzzanatot okoz; jól elhatárolódó, unilocularis, radiolucens laesio kortikált szegéllyel (ritkán multilocularis is lehet); impaktált fogakhoz gyakran társul, ami „follicularis megjelenést” idéz elő

Szövettan: jellegzetes; vékony, orthokeratosist mutató, többrétegú laphám prominens granularis réteggel; a hám-stroma határ egyenletes, a basalis sejtek nem mutatnak paliszádállást; a felszín nem hullámos, vastag lemezes szaruréteg jellemző; focalisan lehet parakeratosis vagy el nem szarusodó laphám, általában gyulladáshoz társultan

2.2. Fejlödési nem odontogen cysta

2.2.1 Ductus nasopalatinus cysta Nem odontogen cysta az anterior maxilla középvonalában; gyakorisági csúcs: 30-60 év között, f/n arány $3 / 1$ körüli; gyakran a szájüreg felé bedomborodó széles alapú duzzanat, olykor mélyebben elhelyezkedő tömlő; középvonalban a metszőfogak mögötti, kemény szájpadlásbeli, jól elhatárolódó, radiolucens, nemritkán szív alakú elváltozás, gyakran kortikált szegéllyel; a metszőfogakat kimozdíthatja, de a fogak vitalitása megtartott, a lamina dura ép; $>6 \mathrm{~mm}$ (a ductus nasopalatinus elfogadott maximális átmérője) és általában $<2 \mathrm{~cm}$

Szövettan: a leggyakrabban többrétegú, el nem szarusodó laphám focalis köbös, hengeres, csillós sejtekkel; ritkábban $(<10 \%)$ kizárólag légúti hám, amely egyébként az esetek kb. felében jelen van gócosan; a falban gyakran neurovascularis kötegek vannak, illetve előfordulhatnak mucinosus mirigyek, porc; gyakori a traumatizáció, gyulladás

$\mathrm{BOC}=$ botryoid odontogen cysta $\mathrm{f}=$ férfi $\mathrm{GOC}=$ glandularis odontogen cysta $; \mathrm{LPC}=$ lateralis periodontalis cysta; $\mathrm{n}=$ nő $; \mathrm{PTCHl}=$ protein patched homolog-1; WHO = Egészségügyi Világszervezet

\section{Eredmények}

Összesen 2 intézményben leletezett 91 minta elemzésére került sor. A hám hiánya, a nem odontogen eredet vagy a nem odontogen cysta végső diagnózis miatt összesen 85 cysta kerülhetett elemzésre [2]. A szövettani vizsgálat kérésének általános feltételei révén minden betegnél ismert volt az életkor és a magyar nevek alapján a nem (100\%). A lokalizációra vonatkozó információt (adott fogakhoz, foghelyekhez való viszonyt) 53 esetben (62\%) közöltek. A tömlök mérete 23 esetben szerepelt, további
2 esetben nagynak jelölték meg a méretet (29\%). A szövettani diagnózist segítő, releváns információt a szövettani kérólapokon 44 esetben (52\%) adtak meg; ugyanakkor ezen segítő információk 18 esetben csak részlegesek voltak (például: a foggyökér körüli viszonyt jelölő, de a fog állapotáról nem szóló megjegyzés). Ebból az is következik, hogy a beküldött anyagok közel felét nem kísérték releváns információk, ső́t egy-egy esetben félrevezető adatokat vagy iránydiagnózist adtak meg (1. és 2. példa).

A következőkben példákkal illusztrálunk ritkább vagy tanulságosabb eseteket. 


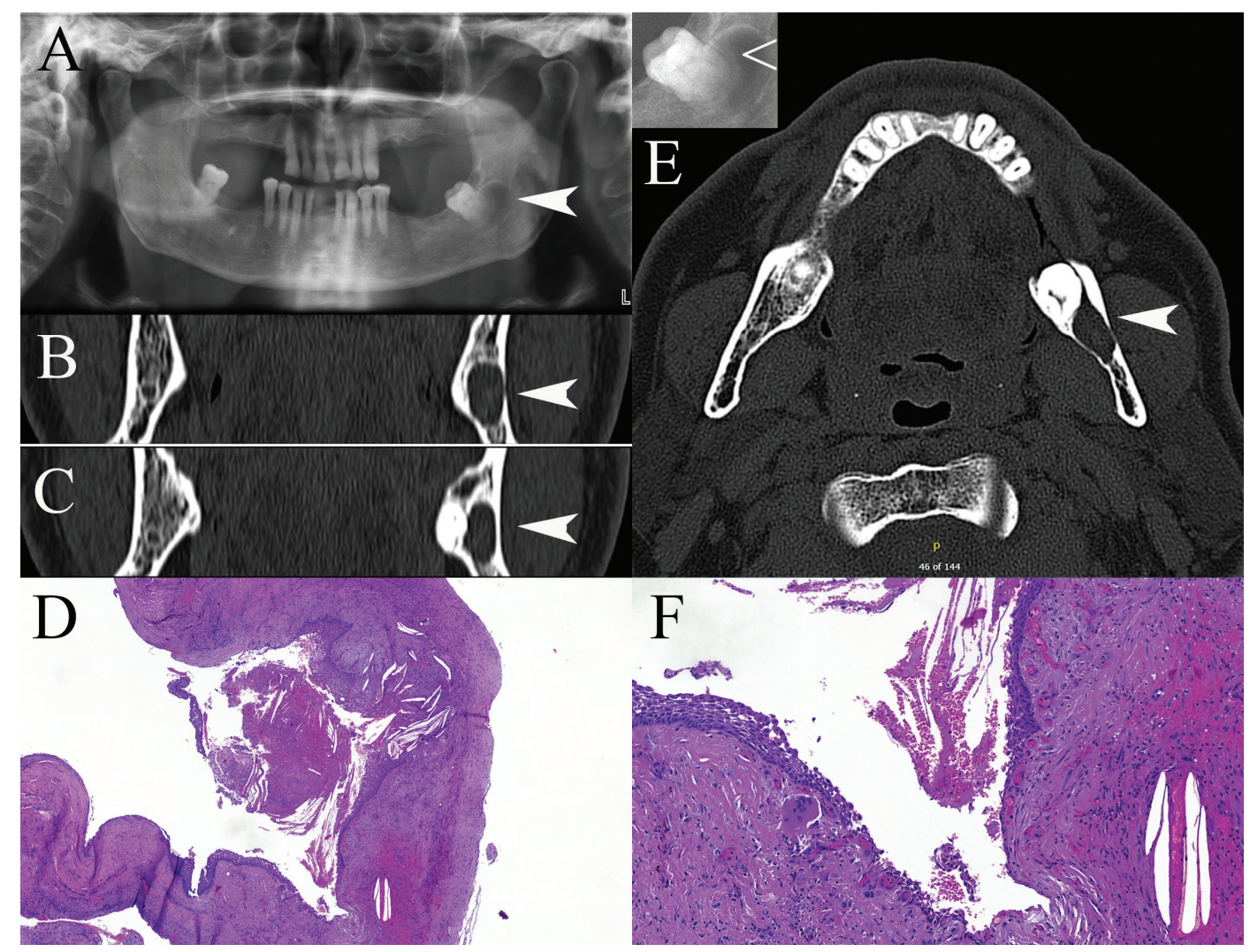

1. ábra

Radicularis cystának véleményezett paradentalis cysta

A: az OPT-felvételen a 38-as fognak megfelelően periapicalis és distalis lokalizációban mutatkozó radiolucens elváltozás van. A kép melletti betéten az elváltozás nagyított képe látható, a fehér nyílhegy a megtartott lamina dura és gyökérhártyarés fehér, illetve fekete sávjára mutat. B-C: a coronalis síkban készült CT-felvételen a cysta foghoz viszonyított distalis (B), illetve buccalis (C) elhelyezkedése látható, ami az axialis felvételen (E) is megfigyelhető. D és F: jellegtelen, többrétegú, el nem szarusodó laphámmal bélelt, koleszteringranulomával szövődött, részben hámfosztott tömlőfal $(\mathrm{HE}, \times 4$, illetve $\times 15)$

$\mathrm{CT}$ = számítógépes tomográfia $; \mathrm{HE}=$ hematoxilin-eozin $; \mathrm{OPT}=$ ortopantomogram

\section{Elsö példa}

Radicularis cystának véleményezett paradentalis cysta (1 ábra)

A közölt klinikai adatok szerint 66 éves férfi, akinek 38-as fogát részlegesen íny fedi, a fog koronája szondázható, OPT (ortopantomogram)-felvételen $2 \mathrm{~cm}$ legnagyobb méretű radiolucens terület van a gyökércsúcs körül. A fogazat parodontopathiás. Szövettanilag lobos, részben hámfosztott, többrétegú, el nem szarusodó laphámmal bélelt tömlőt azonosítottunk koleszteringranulomával (1. ábra, $D, F)$; radicularis cysta diagnózisa született - összhangban a periapicalisnak megjelölt lokalizációval. A panoráma-röntgenfelvételen (1. ábra, $A$ ) látható, hogy bár a tömlő vetülete valóban periapicalisnak tûnik, a periodontalis szalagok terének megfelelő gyökérhártyarés intakt (1. ábra, E betét), ami a radicularis cystát gyakorlatilag kizárja. A CT-felvételeken az is látható, hogy a cysta buccalisan és distalisan helyezkedik el, a fog mellett (1. ábra, $B, C, E$ ). A szövettani kép jellegtelen, inflammatoricus vagy inflammált cysta képének felel meg. A collateralis inflammatoricus cysták közé tartozó paradentalis cysta típusos radiológiai képe alapján lehet az elváltozást helyesen felismerni. A lokalizáció (periapicalis) helytelen leírása, a radiológiai kép tanulmányozásának hiánya, egyes klinikai információk hiánya (a szinte mindig társuló, kísérő pericoronitis említésének hiánya, a fog impaktált voltának elhallgatása) és a jellegtelen szöveti kép, továbbá a tömlőtípus kevésbé ismert volta közrejátszott a diagnózis kisiklásában [3]. A paradentalis cysta egyébként szokatlan ebben az életkorban, kialakulásához a 37-es fog közelmúltban feltételezhetô eltávolítása és az impaktált 38-as fog késői előtörése játszhatott szerepet.

\section{Második példa}

Radicularis cystának véleményezett gyulladt follicularis cysta (2. ábra)

A közölt klinikai adatok szerint 23 éves férfi bal oldali mandibularis cystáját küldték szövettani vizsgálatra, K0110 impaktált fog kódolt diagnózissal. Klinikai diagnózis lényegében nem volt, de a „keratocysta?” szerepelt a beküldólapon. A szövettani kép jellegtelen, inflammatoricus vagy inflammált cysta képének felelt meg, területenként kifejezett krónikus gyulladásos be- 

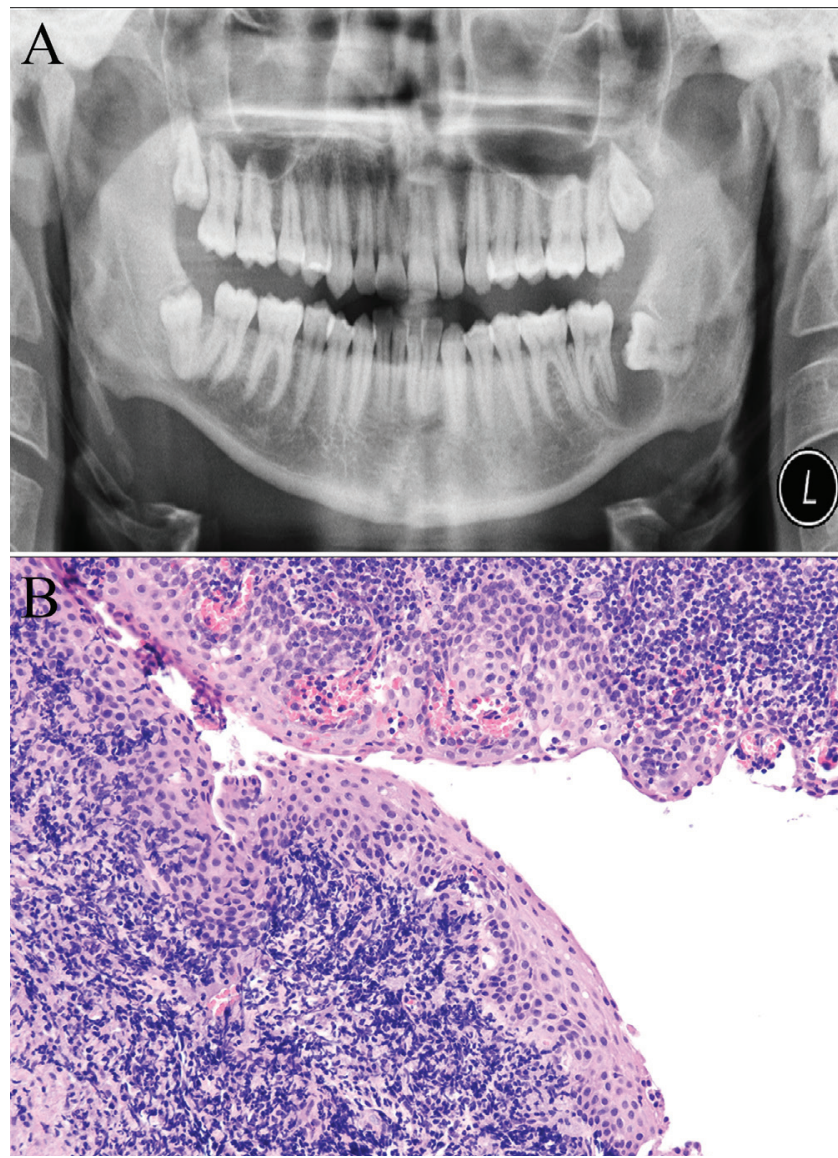

2. ábra

Radicularis tömlőnek véleményezett lobos follicularis cysta

A: az OPT-felvételen a 38 -as fog nyaki régiójával összefüggó „follicularis” jellegű tömlő képe látható intakt gyökerű 37 -es foggal. B: a szövettani kép jellegtelen, dominálóan mononukle áris lobsejtekkel, kisebb részben neutrophil granulocytákkal beszűrt, többrétegű, el nem szarusodó laphámmal bélelt tömlőfal $(\mathrm{HE}, \times 20)$

$\mathrm{HE}=$ hematoxilin-eozin $; \mathrm{OPT}=$ ortopantomogram

szűrődéssel (2. ábra, B). OKC jellegzetes szöveti képe nem mutatkozott, radicularis cysta diagnózisa született. A nem közölt klinikai adatokból megismerhettük, hogy a 38-as fog impaktált, az élő 37 -es fog mögött fluktuáció volt, az eltávolított terület a 38 -as fog körüli radiolucens elváltozásnak felelt meg, amely elérte a 37-es fog gyökerét és a mandibula basisát. A fenti radiológiai leírással összhangban a panorámafelvételen az impaktált 38-as fog nyaki régiójával érintkező, a fog koronáját magában foglaló, lateralis follicularis cysta típusos képe látható (2. ábra, $A$ ). A radicularis tömlő ellen szól, hogy mind a 37-es, mind a 38-as fog épnek látszik, a 38-as fog gyökerével, annak csúcsi részével a tömlő nem érintkezik, a 37-es fog gyökérhártyarése megtartott. A radiológiai képnek és/vagy korrekt leírásának hiánya, a fluktuáció hátterében álló gyulladás okozta másodlagos, aspecifikus szöveti kép a diagnózis kisiklásához vezetett. A sorozatban további két hasonló eset volt.

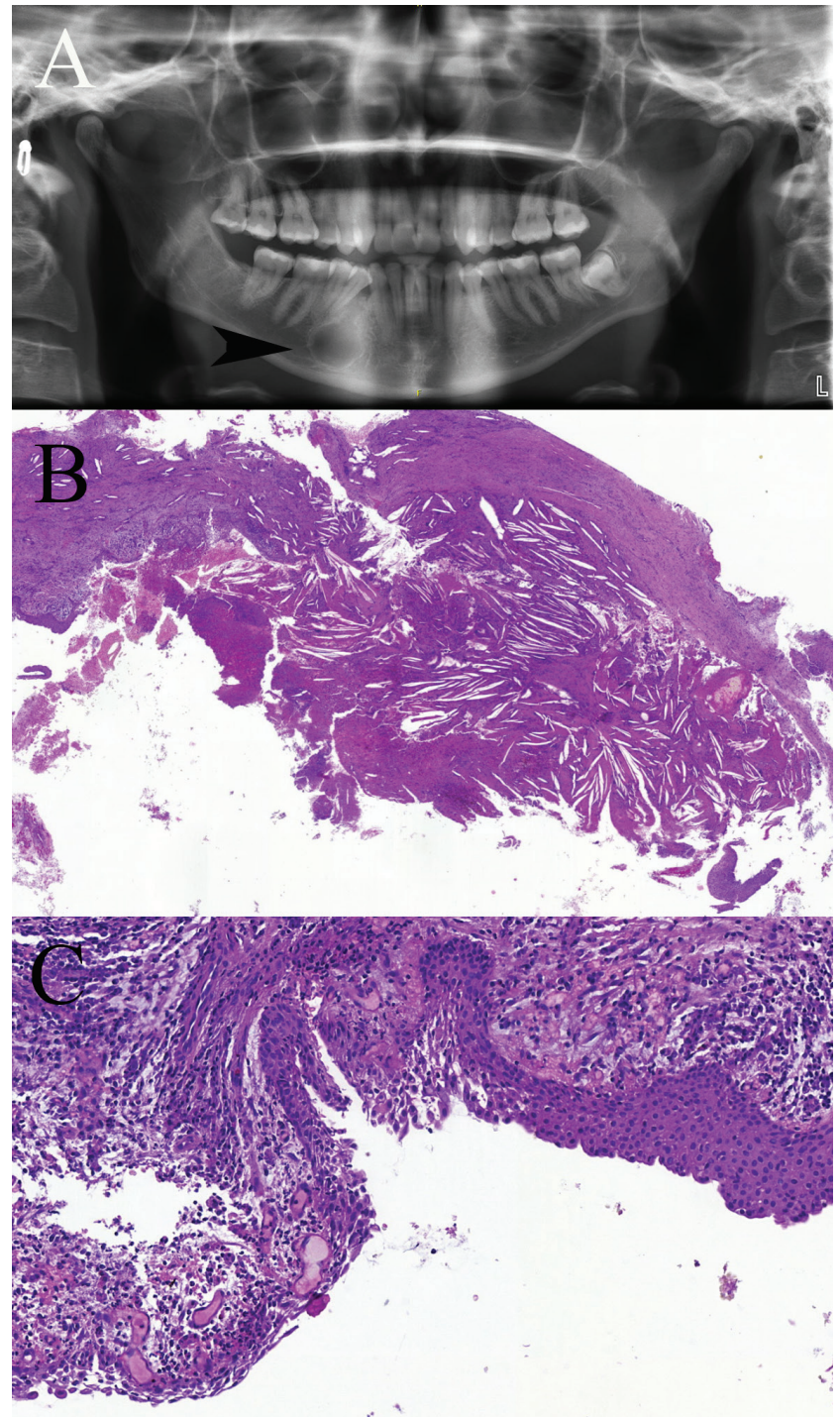

3. ábra

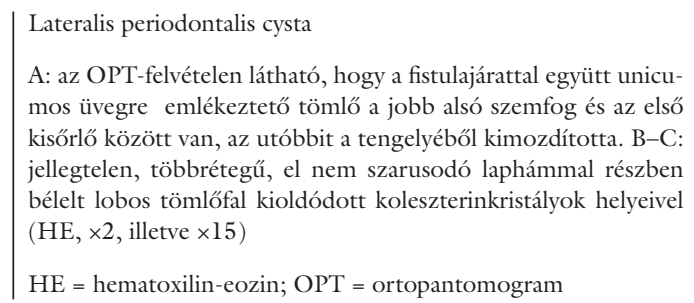

Harmadik példa

Lateralis periodontalis cysta (3. ábra)

A közölt klinikai adatok szerint a 31 éves nő fogazata torlódott, a 44-es, 45-ös fogak tájékán nyomásérzékenység állt fenn vestibularis és lingualis irányokban egyaránt; az elváltozásról 2 éve tudtak. A 44-es és 43-as fog közötti, basisközeli, 2 cm legnagyobb méretú, kör alakú, radiolucens területhez a 44-es fog nyakánál fistulanyílás társult (3/A ábra). Biopszia (próbaexcisio) történt. Ezzel szemben a mútéti leírásból utólag kiderült, hogy a tömlő egésze távozott a műtét kapcsán, amivel összhangban szakadozott tömlő érkezett vizsgálatra. A bel- 
felszín morzsalékony, sárgásbarna volt, és ez mikroszkóposan focalisan lobos, koleszterinkristályok helyeit tartalmazó, többrétegú, el nem szarusodó, bár elvétve dyskeratocytákat tartalmazó, jellegtelen laphámnak felelt meg (3. ábra, $B$ és $C$ ). A szövettani diagnózis lobos odontogen cysta, radicularis cysta lett. A tárolt, de nem közölt klinikai adatokból kiderül, hogy a 43-as és a 44-es fog, amelyek között a tömlő volt, vitálisak, ami kizárja a radicularis cysta diagnózisát. A lokalizáció értelmében egyéb inflammatoricus cysta sem jön szóba, azaz másodlagosan gyulladt (a fistula révén a szájüreggel kommunikáló) fejlődési cystáról, lateralis periodontalis cystáról van szó. A mandibularis metszö- és praemolaris fogak közötti lokalizáció típusos (1. táblázat) [1, 4]. A téves diagnózishoz a jellegtelen gyulladásos kép, a radiológiai kép és a fogak vitalitására vonatkozó információ hiánya, továbbá valószínúleg a tömlőtípus kevésbé ismert volta vezethetett.

\section{Negyedik példa}

A ductus nasopalatinus cysta és a radicularis cysta elkülönítő diagnosztikáját példázó eset (4.ábra)

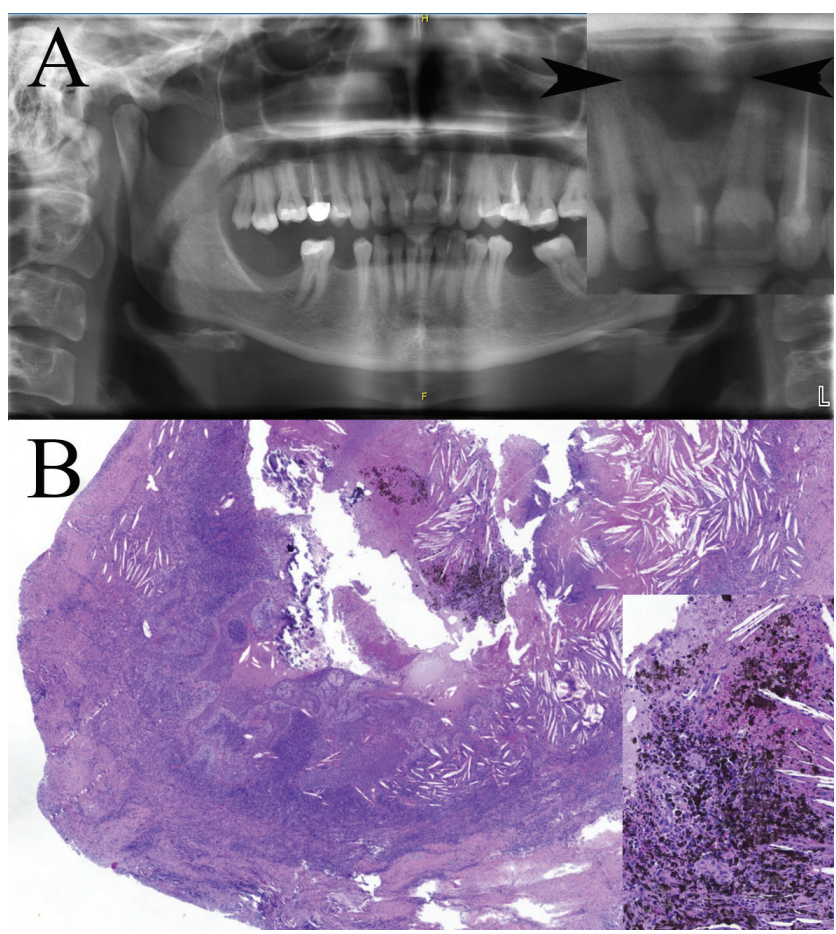

4. ábra

A ductus nasopalatinus (canalis incisivus) és a radicularis cysta differenciáldiagnosztikáját példázó tömlő

A: az OPT-felvételen a 11 -es fog eltolódását okozó, a 11 -es és a 2l-es fog között elhelyezkedő radiolucens elváltozás van; a betéten nagyított részlet a fogakhoz való viszonyt jobban mutatja. B: a szövettani képen lobos laphámbélésú cysta észlelhető, koleszterinkristályok résszerú helyeivel és a betéten nagyítva is lát ható exogén fekete pigmenttel $(\mathrm{HE}, \times 2$; betét, $\times 8$ )

$\mathrm{HE}=$ hematoxilin-eozin; $\mathrm{OPT}=$ ortopantomogram
A klinikai adatok szerint 43 éves nónél a 11 -es és a 2l-es fog között kiterjedt, körülhatárolt radiolucens terület (4. ábra, $A$ ), a 21 -es fognak megfelelően fistulanyílás volt. A 10 mm legnagyobb kiterjedésü, kissé szakadozott falú tömlőt mikroszkóposan többrétegú, el nem szarusodó laphám bélelte, koleszterinkristályok helyei mutatkoztak, a falban krónikus gyulladás jeleivel, ami gyulladásos eredetú vagy gyulladt fejlődési cystákban egyaránt előforduló aspecifikus lelet (4. ábra, B); a szövettani diagnózis radicularis cysta lett. A radiológiai képet figyelembe véve a ductus nasopalatinus cysta fel kell, hogy merüljön, mivel a lokalizáció arra lenne típusos. A klinikai adatok nem említik, hogy a 11 -es vagy a 21 -es fog valamelyike elvesztette volna vitalitását, és röntgenárnyékot adó tömőanyag az OPT alapján egyik fog gyökércsatornájában sem látható. Az adatok a fogcsúcshoz való viszonyról sem tesznek említést, de a röntgenképen látható, hogy részben periapicalis a megjelenés. A periodontalis rés - különösen a 11 -es fognál - nem ítélhető meg. CT-felvétel, intraoralis röntgen segítséget nyújtott volna a labialis-palatinalis kiterjedés megítélésében, de nem állt rendelkezésre. A rendelkezésre álló adatok alapján a ductus nasopalatinus cysta a valószínúbb, de a szövettani vizsgálat során a gyulladásos tömlőtartalomban exogén pigmentanyag is mutatkozott, amely nagy valószínúséggel tömőanyagnak felel meg, és emiatt a tömlő mégis radicularis cysta lehet. A szövettani kép döntő szerepet játszott a differenciáldiagnosztikai dilemma egyik irányba való elmozdításában. Megjegyzendő, hogy az esetben atípusos, hogy a tömlő fog elmozdulásához vezetett, mert ez radicularis cysták esetén csak kivételesen fordul elö [5], míg ductus nasopalatinus cystáknál nem ritka jelenség [6].

\section{Ötödik példa}

Szokatlan lokalizációjú botryoid odontogen cysta (5. ábra)

A klinikai adatok szerint 72 éves nó 12 -es, 11 -es és 21-es fogának megfelelő periapicalis cysta került eltávolításra. A szövettani metszetekben a multilocularis tömlő részben vékony, többnyire kétrétegü hámot mutatott, amely területenként plakkszerüen kiszélesedett; a hám alatt gócosan hialinizált, dens kötőszöveti réteg mutatkozott, és a hám több helyen levált az alapjáról. A szövettani diagnózis az aspecifikus „cysta maxillaris” volt. A látott hisztológiai jegyek a lateralis periodontalis, botryoid és felnőttkori gingivalis tömlők szövettani képére jellemzőek, amelyek közül csak a botryoid tömlő multilocularis; így ez a pontosabb diagnózis. A botryoid tömlők közel 80\%-a mandibularis, férfiakban és idősebbeknél, a 6-7. évtizedben gyakoribbak, és ezek közül csak az utóbbi állt közel a jelen eset paramétereihez.

A klinikai adatokat, a radiológiai megjelenést és a szövettani képet - a lehetőségekhez mérten - együttesen figyelembe vevő revíziót követően az eredeti szövettani 

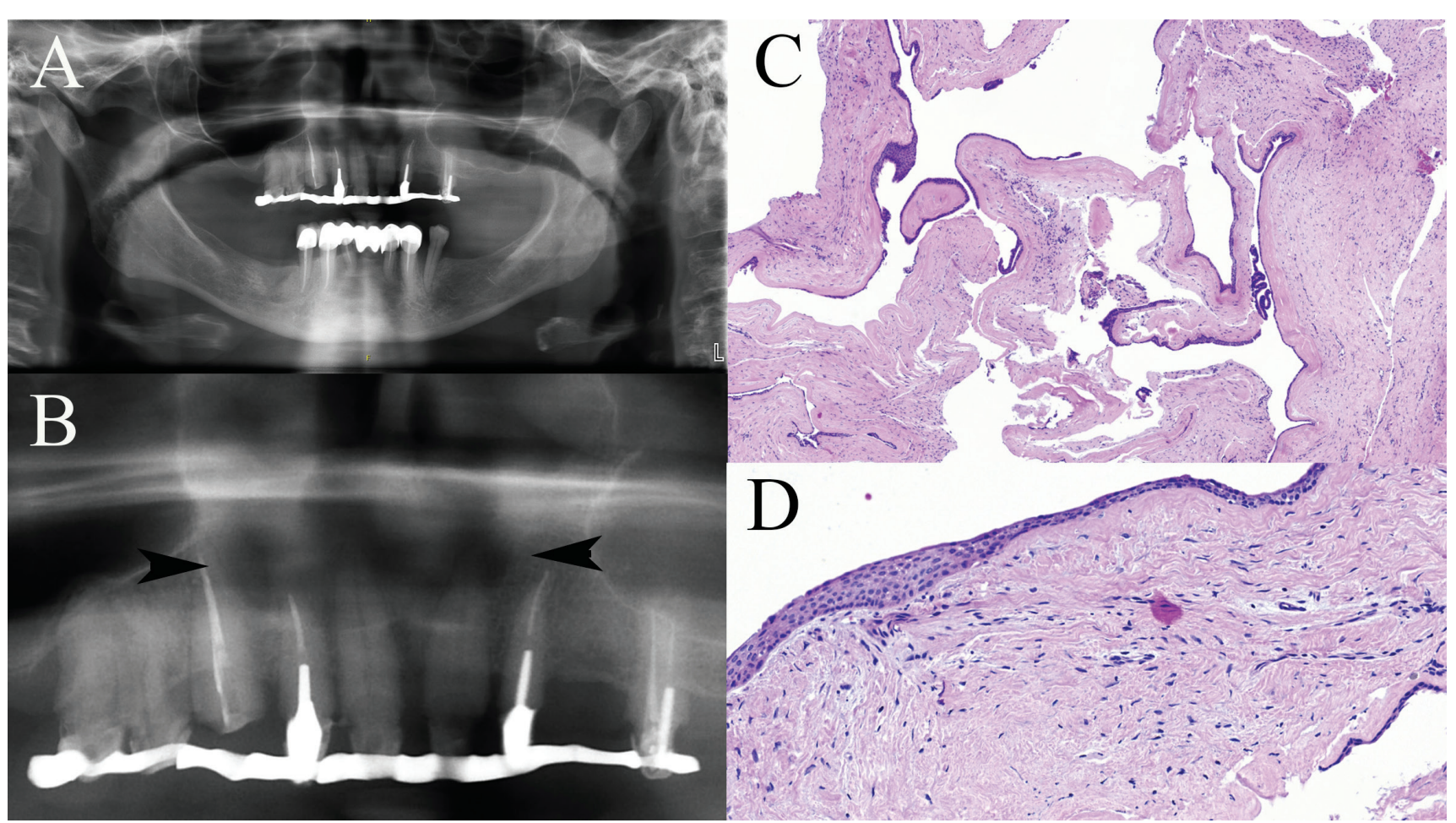

5. ábra

Botryoid odontogen cysta

A-B: az OPT-felvételen és nagyított részletén (B) multilocularis tömlőnek megfelelő radiolucens elváltozás látható. C-D: a multilocularis tömlőt vékony, helyenként kissé kiszélesedő hám béleli $(\mathrm{HE}, \times 5$, illetve $\times 20)$

$\mathrm{HE}=$ hematoxilin-eozin $; \mathrm{OPT}=$ ortopantomogram

diagnózis 38/85 esetben (45\%) módosítást igényelt. A módosítások magukban foglaltak olyanokat is, amelyeknél a „gyulladásos cysta” eredeti kórisménél specifikusabb diagnózist is sikerült adni, illetve 6 olyan esetet is, amelynél a rendelkezésre álló adatok alapján nem lehetett pontosabb véleményt, iránydiagnózist vagy diagnózist adni, mint a gyulladásos vagy gyulladt fejlődési tömlő. Öt esetben OKC vagy gyulladt OKC került másként megjelölésre a szövettani leletben, illetve egyben lobos follicularis tömlő került lobos OKC-ként megjelölésre. A klinikai diagnózisokkal az összevetés lehetetlen volt az esetek nagy részében, mivel nem szerepeltek, vagy csak az OKC, illetve a malignitás kizárására irányuló kérdést tükröztek.

A 4 további egyetemi patológiai intézetból 10-10, egymást követő állcsonti cysta anonimizált leletének megküldésére irányuló kérésre 3 intézetből érkeztek leletek, mivel a negyedikben nem leleteznek ilyen típusú anyagokat. Ezekben a rögzített klinikai adatok 8/10, $5 / 12$, illetve $8 / 10$ esetben adtak támpontot a lokalizációra. Méretre vonatkozó adat 1 intézet 2 anyagához, radiológai leírás vagy mellékelt kép ugyanezen intézet 3 anyagához társult. A diagnózis szempontjából releváns adat 4/10,6/12 és 10/10 esetben került rögzítésre, de ezek egy része hiányos volt. A cysták mibenlétére vonatkozó klinikai iránydiagnózis $2 / 10,6 / 12$, illetve 9/10 alkalommal szerepelt a beküldőlapon. A szövettani diagnózisok között előfordult OKC diagnózisa el nem szaru- sodó laphámbélés mellett, keratocysta-residuum „keratocysta?, residualis cysta?" kérdéses iránydiagnózisokra válaszolva; és egy helyen az esetek 9/10 részének follicularis cysta/folliculus lett a szövettani eredménye, ami a gyakorisági adatok és az esetek random szelekciója alapján felveti a helytelen besorolások lehetőségét is.

Az eredeti tanulmány $50+35$ tömlőjét 7 , illetve 5 különböző patológus valamelyike leletezte; a 3 más intézetből küldött eseteket 2 intézetben 6 , illetve 7 patológus valamelyike adta ki, míg a harmadik intézetben mindet 1 patológus véleményezte.

\section{Megbeszélés}

Korábbi vizsgálataink 2 intézmény napi gyakorlatába engedtek betekintést $[2,7]$, és ezt szúrópróbajelleggel kiegészítette további 3 intézmény néhány leletének áttekintése. Ezek alapján úgy tünik, hogy az oralis patológia tárgykörébe tartozó állcsonti cysták diagnosztikája több helyen mind a maxillofacialis sebészet, mind a patológia részérôl elhanyagolt. A háttérben több tényezó állhat.

Kevés tömlő pontos mibenlétének van komolyabb klinikai jelentősége. Az OKC-k Gorlin-Goltz-szindrómához való esetenkénti (kb. $5 \%$ arányú) társulása, gyakori lokálisan agresszív növekedése és recidívahajlama külön jelentőséget ad ennek a típusnak [1, 8, 9], amely viszont klinikai/radiológiai megjelenésében olykor átfedést mutathat a follicularis tömlővel $[10,11]$, a residualis tömlő- 
vel vagy akár az unicysticus ameloblastomával [12] vagy egyéb, ritkább odontogen tumorokkal [13]. Emiatt a szövettani verifikáció jelentőséggel bír, különösen azáltal, hogy a szöveti kép alapesetben jellegzetes. Sok más tömlő pontos mibenléte inkább csak a diagnosztikus szakma múvészi szintû (lege artis) múvelése, precizitást megcélzó igény kielégítése szempontjából jelentős, ellátásuk gyakran nagyon hasonló. Megjegyzendő az is, hogy a diagnosztikai helyzet alapvetően eltérő, ha felállított klinikai kórisme esetén az eltávolított tömlőt a törvényi előírásnak megfelelve szövettani vizsgálatra küldik megerősítésre, illetve ha bizonytalan a klinikai diagnózis, és emiatt biopszia történik a cysticus laesio kezelésének tervezése céljából; az utóbbi jelentôsége nyilvánvalóan nagyobb, és a kórisme felállítása kis mintából nehezebb.

Mind a patológusok, mind az ellátó klinikusok kevésbé ismerik a tömlők 80-90\%-át kitevő három leggyakoribb tömlő (a radicularis - és a vele összefüggő residualis - cysta, a follicularis cysta és az OKC) mellett a többi, típusonként 1-5\% körüli vagy ez alatti gyakorisággal rendelkező tömlőt. A kellő létszámmal rendelkező osztályokon, intézetekben a patológusok körében is valamilyen fokú specializáció áll fenn, de az odontogen cysták kevés helyen tartoznak egy vagy egy-két patológus érdeklődési területéhez. A jelen közlemény alapanyagát képező 85 tömlőt 2 intézetben összesen 12 különböző patológus valamelyike leletezte, és hasonló jelenséget tükröztek 2 más intézetből küldött leletek is: egymástól függetlenül 6 , illetve 7 orvos véleményezte a 10-10 áttekintett leletet. Csupán 1 patológiai intézetben utalt specializációra az egyetlen orvostól származó 10 lelet, illetve az, hogy olykor radiológiai képet is mellékeltek a szövettani mintához. A nem speciális érdeklődéssel bíró patológusok jelentős része nem ismeri a jellegzetes szöveti képet adó, ritkább fejlődési vagy gyulladásos tömlők klinikai, radiológiai vonatkozásait. A gyulladt fejlődési cysták szövettani képe adott esetben semmiben sem különbözik egy gyulladásos tömlő szövettani képétől, amely alapján sok „radicularis cysta” diagnózis születik azzal inkoherens klinikai, radiológiai kontextusban, tévesen. Hasonló módon, az érett, gyulladásos eredetû tömlők a lelohadt gyulladást követően olykor téves „follicularis cysta” diagnózishoz vezethetnek. A hibák elkerülése érdekében fontos volna rendszeresen használni a digitális medikai rendszerekben gyakran jelen lévő képfeltöltési és megtekintési funkciókat.

$\mathrm{Ha}$ ismert lenne is a klinikoradiopatológiai jellemzők köre, a nem közölt adatok sok esetben akkor sem tennék lehetővé a helyes diagnózis felállítását. Eseteink kapcsán nagyon magas arányban nem volt feltételezett klinikai diagnózis, amelyet közöltek volna a szövettani konzílium kérésekor. Ennek pontos mértékét nehéz lenne meghatározni, mivel sok esetben a klinikum szempontjából kiemelten lényeges „keratocysta?” eldöntendő kérdés szerepelt a kérőlapon. Egy angol tanulmány szerint follicularis tömlőként félrediagnosztizált OKC-k és ameloblastomák (illetve félrediagnosztizált ameloblastomák) kapcsán a rosszul értelmezett szöveti kép mellett a helytelen klinikai adatközlés, a radiológiai jellegzetességek (klinikusok és/vagy patológusok általi) figyelmen kívül hagyása játszott szerepet a tévedésekben [14].

Az odontogen tömlőknek sok esetben van predilekciós helyük (1. táblázat) [1, 15], illetve jellegzetes klinikai korrelációjuk (például a radicularis cysták nem vitális foghoz, a follicularis cysták impaktált foghoz vagy a paradentalis cysták pericoronitishez való társulása). A fogak vitalitására, állapotára, a tömlők lokalizációjára vonatkozó információk ezért alapvetőek a helyes diagnózis felállításához. A tömlők méretére vonatkozó információ is segítséget nyújthat: a radicularis tömlők például általában kis méretűek, bár a kivételek erősíthetik a szabályt [5]. A klinikai/radiológiai méret közlése azért is lehet lényeges, mert az eltávolított cysta gyakran összeesik, illetve ha darabokban kerül eltávolításra, akkor a mérete még csak hozzávetólegesen sem rekonstruálható; biopszia esetén a patológiai minta nem ad információt a méretre. A diagnózist segítő releváns információk magas arányú közlésére csak 1 intézetben lehet következtetni az elemzett minták alapján. Máshol az esetek akár több mint felében hiányozhatnak ezek az információk, s ez alapján precíz diagnózis csak a nem gyulladt fejlődési cysták némelyikénél (például OKC) várható, amelynél a szövettani kép a döntő; bár ez sem mindig egyértelmü, és a diagnosztika képelemzéssel itt is javítható [16]. Különösen fiatal korú beteg esetén ajánlják az oralis/maxillofacialis patológiában jártas patológus bevonását is a diagnosztikába, annak tisztázására, hogy a leletek konzisztensek-e a klinikai, radiológiai képpel [14].

Előfordult, hogy keratocysta szövettani diagnózisát úgy állították fel, hogy erre a klinikai adatok nem utaltak, és a hámbélés el nem szarusodó laphámnak lett leírva, ami nem zárja ki ezt a diagnózist [2], de mindenképpen magyarázatot igényelt volna. Bár kis esetszámból nem lehet megfelelő statisztikai következtetéseket levonni, elemzésünk rámutat arra, hogy az odontogen tömlők precíz diagnosztikája mind a klinikai, mind a patológiai oldalról javítást igényel, aminek egyik része az ilyen irányú képzés lehet. Cikkünk megírásával ezt a célt óhajtottuk szolgálni.

Anyagi támogatás: A szerzők a kézirat megírásához anyagi támogatásban nem részesültek.

Szerzôi munkamegosztás: Minden szerző részt vett az adatok gyưjtésében, összefoglalásában és a kézirat végleges formájának kialakításában. Ezenfelül Cs. G., Cs. D., Z. T. az ábrák elkészítésével, Cs. G., Cs. D., B. Z. a klinikoradiopatológiai korreláció elvégzésével is hozzájárult a közleményhez. A cikk végleges változatát minden szerző jóváhagyta.

Érdekeltségek: A szerzőknek a közleménnyel kapcsolatos érdekeltségülk nincs. 


\section{Köszönetnyilvánítás}

A szerzők ezúton mondanak köszönetet a betegek kórismézésében, kezelésében vagy az elemzett adatok rögzítésében, gyưjtésében, továbbításában játszott szerepükért alfabetikus sorrendben a következő munkatársaiknak (mind a Szegedi Tudományegyetemen, mind annak Bács-Kiskun Megyei Oktatókórházában; kivéve, ahol másként került feltüntetésre): $d r$. Cseh Dóra, dr. Hajnal-Papp Rozália (†), dr. Klement Edina, dr. Kocsis Lajos, prof. dr. Mébes Gábor (Debreceni Tudományegyetem, Patológiai Intézet), $d r$. Raul Anita, $d r$. Sass Tamás, dr. Szoboszlay Ágnes, dr. Tornóczky Tamás (Pécsi Tudományegyetem, Pathologiai Intézet), dr. Vágó Tibor, dr. Zalatnai Attila (Semmelweis Egyetem, I. Patológiai és Kísérleti Rákkutató Intézet). Külön köszönet illeti Paul Speight professor emeritust (University of Sheffield, School of Clinical Dentistry), aki egyes, itt elemzett, bemutatott tömlők kapcsán konzíliumi véleményt adott, illetve megerősítette a diagnózisokat.

Az összetett ábrák OPT-részei korábbi (az irodalom [2] tételeként szereplő) nyílt hozzáféréssel (Open Access) megjelent közleményünk 593 oldalas kiegészítő anyagának 1016 képe között szerepeltek, és a Creative Commons licenc alapján (http://creativecommons.org/licenses/ by/4.0) szabadon felhasználhatók.

\section{Irodalom}

[1] El-Naggar AK, Chan JK, Grandis JR, et al. (eds.) WHO classifi cation of head and neck tumours, 4 th edn. International Agency for Research on Cancer, Lyon, 2017.

[2] Cserni D, Zombori T, Vörös A, et al. A clinicopathological approach to odontogenic cysts: the role of cytokeratin 17 and bcl2 immunohistochemistry in identifying odontogenic keratocysts. Pathol Oncol Res. 2020; 26: 2613-2620.

[3] Silva TA, Batista AC, Camarini ET, et al. Paradental cyst mimicking a radicular cyst on the adjacent tooth: case report and review of terminology. J Endod. 2003; 29: 73-76.

[4] de Carvalho LF, Lima CF, Cabral LA, et al. Lateral periodontal cyst: a case report and literature review. J Oral Maxillofac Res. $2011 ; 1(4)$ : e5.

[5] Deshmukh J, Shrivastava R, Bharath $\mathrm{KP}$, et al. Giant radicular cyst of the maxilla. BMJ Case Rep. 2014; 2014: bcr2014203678.
[6] Sankar D, Muthusubramanian V, Nathan JA, et al. Aggressive nasopalatine duct cyst with complete destruction of palatine bone. J Pharm Bioallied Sci. 2016; 8(Suppl 1): S185-S188.

[7] Cserni D, Zombori T, Stájer A, et al. Immunohistochemical characterization of reactive epithelial changes in odontogenic keratocysts. Pathol Oncol Res. 2020; 26: 1717-1724.

[8] Pogrel MA. The keratocystic odontogenic tumour (KCOT) - an odyssey. Int J Oral Maxillofac Surg. 2015; 44: 1565-1568.

[9] Gurdán Z, Gelencsér G, Lengyel Z, et al. The complex dental and oral surgical management with 8-year follow up of a GorlinGoltz syndrome patient. [Gorlin-Goltz-szindrómás beteg komplex fogorvosi, szájsebészeti kezelése és 8 éves követése.] Orv Hetil. 2020; 161: 67-74. [Hungarian]

[10] Karabas HC, Ozcan I, Tekkesin MS, et al. Evaluation of radiolucent lesions associated with impacted teeth: a retrospective study. Curr Med Imaging 2020 Feb 5. Doi: 10.2174/157340561666 6200206115827. PMID: 32107998. [Epub ahead of print]

[11] Chaudhary S, Sinha A, Barua P, et al. Keratocystic odontogenic tumour (KCOT) misdiagnosed as a dentigerous cyst. BMJ Case Rep. 2013; 2013: bcr2012008741.

[12] Myoung H, Hong SP, Hong SD, et al. Odontogenic keratocyst: Review of 256 cases for recurrence and clinicopathologic parameters. Oral Surg Oral Med Oral Pathol Oral Radiol Endod. 2001; 91: 328-333.

[13] More CB, Das S, Gupta S, et al. Mandibular adenomatoid odontogenic tumor: radiographic and pathologic correlation. J Nat Sci Biol Med. 2013; 4: 457-462.

[14] Barrett AW, Sneddon KJ, Tighe JV, et al. Dentigerous cyst and ameloblastoma of the jaws: correlating the histopathological and clinicoradiological features avoids a diagnostic pitfall. Int J Surg Pathol. 2017; 25: 141-147.

[15] Shear M, Speight PM. Cysts of the oral and maxillofacial regions, 4th edn. Blackwell Publishing Ltd, Oxford, 2007.

[16] Florindo JB, Bruno OM, Landini G. Morphological classification of odontogenic keratocysts using Bouligand-Minkowski fractal descriptors. Comput Biol Med. 2017; 81: 1-10.

(Cserni Gábor dr., Kecskemét, Nyíri út 38., 6000 e-mail: cserni@freemail.hu)

\section{"Virtuti melius quam fortunae creditur." (Jobb az erényben bíznod, mint a szerencsében.)}

A cikk a Creative Commons Attribution 4.0 International License (https://creativecommons.org/licenses/by/4.0/) feltételei szerint publikált Open Access közlemény, melynek szellemében a cikk bármilyen médiumban szabadon felhasználható, megosztható és újraközölhető, feltéve, hogy az eredeti szerző és a közlés helye, illetve a CC License linkje és az esetlegesen végrehajtott módosítások feltüntetésre kerülnek. (SID_1) 